\title{
Events that lead university students to change their major to Information Systems: A retroductive South African case
}

\author{
Lisa F Seymour, Thabang Serumola \\ CITANDA, Department of Information Systems, University of Cape Town, South Africa
}

\begin{abstract}
Shortage of computing skills is a global concern as it affects national development and business success. Yet, despite high job availability and high salaries in computing professions, insufficient numbers of students are choosing to study the various computing disciplines. This South African study looks at the Information Systems (IS) major which is misunderstood by high school students. This retroductive case study identifies the events which lead students to change their major to IS. The study confirms the importance of interest in a major as well as the perceived high value of a major, which feature as dominant factors in the literature. Yet these are not the initial events that lead to students changing their major to IS. Events that initiate the process include losing passion for a previous major, experiencing difficulty in a previous major as well as enjoying the introductory IS course. The paper has practical advice for IS Departments and argues for a generic first year for students as well as a focus on enjoyment and skills aligned to IS professional practice in introductory IS courses. These findings can be generalised to other majors and, hence, the theoretical contribution adds to the literature on career choice in general.
\end{abstract}

Keywords: ICT skills, Information systems careers, IS major, computing curricula

Categories: Social and professional topics $\sim$ Computing education, Applied computing $\sim$ Education

Email:

Lisa F Seymour lisa.seymour@uct.ac.za (CORRESPONDING),

Thabang Serumola phomolo.serumola@alumni.uct.ac.za
Article history:

Received: 14 December 2015

Accepted: 30 May 2016

Available online: 20 July 2016

\section{INTRODUCTION}

The shortage of computing skills is a global problem (Schofield, 2014). This is of concern as information communication technology (ICT) is the platform on which most, if not all, businesses depend to carry out daily operations (Breytenbach, 2013). Hence, a lack of computing skills will limit economic growth and will have adverse consequences on a nation's ability to be competitive. The outsourcing of computing skills abroad due to skills shortages is seen to be hurting the South

Seymour, L. and Serumola, T. (2016). Events that lead university students to change their major to Information Systems: A retroductive South African case. South African Computer Journal 28(1), 18-43. http://dx.doi.org/10.18489/sacj. v28i1.367

Copyright (C) the author(s); published under a Creative Commons NonCommercial 4.0 License (CC BY-NC 4.0). $S A C J$ is a publication of the South African Institute of Computer Scientists and Information Technologists. ISSN 1015-7999 (print) ISSN 2313-7835 (online). 
African economy and reducing competitiveness (Moyo, 2015). This is avoidable, especially when one considers our high youth unemployment (Schofield, 2014).

While computing and ICT are different terms, they are often used interchangeably and are therefore used as such in this paper. Predictions from the United States Department of Labor indicate that 73\% of new Science, Technology, Engineering and Mathematics (STEM) jobs in the United States through 2020 will be in Computing (US Department of Labor, 2010). Because of the constantly evolving ICT industry, new ICT job roles are being introduced, such as IT Architect, Social Network Manager and Web Specialists (Calitz, Greyling, \& Cullen, 2011). As more ICT jobs are created, skills shortages are predicted to increase (Lotriet, Matthee, \& Alexander, 2010).

Increased student enrolments into computing disciplines could provide relief, but it seems that the number of high school graduates in South Africa and abroad who are interested in pursuing careers in ICT is not increasing sufficiently (Finnie \& Norrie, 2013; Mui, Tee, \& Sien, 2013). One further contributing factor is mathematics in high school. In South Africa, results of the Grade 12 examination are used to determine entrance into university for a particular degree (Galpin \& Sanders, 2007). In order to be accepted at university to study computing, a sound overall performance and a good pass in Mathematics is usually required (de Villiers, Johnson, \& Cremer, 2012). Recently, Grade 12 results have revealed a drastic reduction in the number of high school students writing mathematics (over 20\%); this reduction translates into fewer students being able to choose to study computing at university (Deloitte South Africa, 2014). These two factors are contributing to a predicted worsening computing skills shortage in South Africa (Alexander \& Twinomurinzi, 2012; Calitz et al., 2011; Cohen \& Parsotam, 2010).

There are a number of computing disciplines; ACM defines the five prominent disciplines as computer engineering, computer science, information systems (IS), information technology and software engineering (Shackelford et al., 2006). There are many reasons why working in computing should be attractive. Firstly, computing careers have one of the most competitive starting salaries in the world, with IT Managers, Software Engineers and Consultants listed under the best paying jobs currently in South Africa (Mikva, 2015). IS majors received the highest average starting salary among the United States 2014 bachelor's business graduates (National Association of Colleges and Employers, 2014a) and computer science and IS are the only non-engineering majors among the top 10 highest paid bachelor's graduates (National Association of Colleges and Employers, 2014b). Secondly, computing careers are evolving as new jobs types are created and new technologies are introduced; this gives computing careers their competitive edge (Calitz et al., 2011).

Insufficient computing enrolments, therefore, raise concerns as to whether students are making appropriate career choices and are knowledgeable about the different computing careers available (Hendriks, 2013). In particular, IS enrolments globally have been seen as problematically low for a few years (Govender \& Naidoo, 2013; Whelan \& Firth, 2012)) and the international IS 2010 curriculum document refers to an IS enrolment crisis (Topi et al., 2010). IS professionals are described as responsible for the planning, development or acquisition, implementation and management of IT infrastructure, data and enterprise-wide software applications (University of Cape Town, 2015). The IS discipline prepares students to be IS professionals yet prior studies have shown that the IS discipline suffers from significant misperceptions among high school students (Seymour, Hart, 
Haralambous, Natha, \& Weng, 2005). Attempts can be made to address these misperceptions at university. The research question then asked is: What events contribute to students changing their major to IS once at university?

\section{MISPERCEPTIONS OF COMPUTING}

While the differences between the various computing disciplines have been defined, in South Africa they are not understood at high school level and often are not even understood at university level (Seymour et al., 2005). This is further confused by students from the different computing disciplines following overlapping career paths (Tanner \& Seymour, 2014) and non-uniform division and naming of computing disciplines in South Africa (Sanders \& Alexander, 2015). Hence in this paper we use the broad term "computing field" to refer to all computing disciplines.

Research has found that perceptions of the computing field from high school goers, referred to as pupils in this paper, varies based on gender, culture and factors such as experience with computers (Cloete, 2011). A 2014 survey of IT workers in South Africa showed only 21\% of respondents being female (Schofield, 2014). Women are often underrepresented in computing disciplines and careers as they expect the field to be dominated with mathematics and programming requirements, and they consider themselves unfit for a career in this field (Mishra et al., 2013). This expectation is not entirely true and hence the computing field is misperceived as being more appropriate for men (Mishra et al., 2013).

Students often dismiss studying computing because they perceive the field to be predominantly technology-oriented (Cheryan, Plaut, Handron, \& Hudson, 2013). The film industry has portrayed ICT professionals in a stereotypical manner with movies such as 'The Social Network', which portray ICT professionals as lacking interpersonal skills and always working on computers (Cheryan et al., 2013). This is a misperception as, in many computing disciplines, interpersonal skills are equally important to technical skills (Cheryan et al., 2013), and in IS often more important (Chakabuda, Seymour, \& van der Merwe, 2014).

\section{IS CAREER CHOICE LITERATURE}

The factors that influence pupils choosing a major has been studied. The literature on economic modelling for college career choice has shown that future expected earnings, preference for work and ability to do coursework are dominant career choice factors (Arcidiacono, Hotz, \& Kang, 2012) as well as enjoying coursework, finding fulfillment in potential jobs, and gaining the approval of parents (Zafar, 2013). Differences between genders have been found with female students considering nonpecuniary outcomes at university as most important while pecuniary or financial outcomes realisedat the workplace are important for males (Zafar, 2013). An explanation given to the gender imbalance within computing, is the perception of IT acquired by school pupils at an early age (Volman \& van Eck, 2001). Females tend to have a less positive outlook and self-esteem about their own computing skills and the value of computing, than males (Volman \& van Eck, 2001). In addition, 
when adolescents are faced with making adult decisions, the perception that IT is a domain for males is pronounced amongst both males and females (Seymour et al., 2005). Career choice research and the studies just mentioned have been criticised as they examine influences as disconnected items and without a theoretical framework (Downey, McGaughey, \& Roach, 2011).

\subsection{The career choice model}

The Career Choice Model (CCM) for computing students posits that career choice is influenced by social, structural and individual factors which are in turn influenced by the cultural context. Structural factors (such as teachers and career advisors) can influence social factors (Adya \& Kaiser, 2005; Lotriet, Matthee, \& Alexander, 2011). The career choice model has been criticised as findings have shown that structural and individual factors are not independent (Lotriet et al., 2011).

\subsection{Social cognitive career theory (SCCT)}

The Social Cognitive Career Theory (SCCT) was therefore chosen as a useful theory for this research as it show the influence of structural and individual factors. SCCT also shows how basic career interests develop over time and has been applied to career choices made by pupils choosing to study IS (Akbulut \& Looney, 2007; Cohen \& Parsotam, 2010). It is based on Bandura's social cognitive theory (Lent, Brown, \& Hackett, 2002). According to SCCT, social and structural factors impact career choice indirectly through individual factors. SCCT is also richer than CCM as individual factors are differentiated into four separate themes namely outcome expectations, self-efficacy, performance attainment, and interest. Interest in academic careers is seen as a joint outcome of self-efficacy beliefs and outcome expectations. These are in turn impacted by aptitudes and past experiences (Lent et al., 2002).

\subsection{The theory of reasoned action (TRA)}

The second theory chosen was the Theory of Reasoned Action (TRA), which has been applied to choosing business majors and IS in particular (Downey et al., 2011). According to TRA, a student's attitude toward choice of major influences their intention to work in that discipline. Their attitude towards their major is influenced by individual factors or beliefs. In TRA, individual factors are separated into two categories: experiential beliefs such as difficulty of the major, aptitude in the major and its workload, and normative beliefs such as interest in the field of work, job security and availability, social and personal image. A student's intention to work in a discipline is not only influenced by attitude toward the major, but also by the influence of salient others in his/her life, collectively referred to as subjective norm (Downey et al., 2011).

\subsection{Socio-structural and subjective norm factors}

All three theories consider socio-structural and subjective norm factors as significant influences on career choice. At university, these factors represent institutional support available to students in 
pursuit of their careers such as lecturer/career advisor, technology access and institutional educational arrangements (Lotriet et al., 2011). These factors also appear to be contextual and vary between high school and university. For example, parents have been shown to be a prominent source factor at high school, while teachers and career advisors are rated poorly (Alexander \& Twinomurinzi, 2012). In contrast, at university, the influence of other students has been found to be the only prominent source factor and plays a negative role in terms of IS attitude (Downey et al., 2011). The authors found few studies that investigate socio-structural factors at university that impact career/major choice, for example Croasdell, McLeod, and Simkin (2011) focused solely on individual and subjective norm factors. Lotriet et al. (2011) researched one socio-structural aspect, namely internet connectivity and its impact on computing majors.

SCCT interest factors for working as an IS professional include linking business and technology, practical application of coursework and perceived daily variety (Ferratt, Hall, Prasad, \& Wynn, 2010). SCCT outcome expectations can be physical, social or self-evaluative. Social and physical outcome expectations factors include perceptions concerning the IS profession, job opportunities, career, importance and relevance in society. These are partly dependent on personal knowledge of prospective working environments and partly by perceptions created by social factors (Breytenbach, 2013). These individual factors would be considered normative beliefs in TRA.

\subsection{Experiential beliefs}

According to SCCT, perceived self-efficacy would influence a pupil's choice of effort, tasks, and achievement (Kuo, Tseng, Lin, \& Tang, 2013). This would include computer self-efficacy as well as subject self-efficacy (Alexander \& Twinomurinzi, 2012). These individual factors are considered experiential beliefs in TRA.

\subsection{Career choice events}

Factors that affect students choosing any computing degree and how the factors relate to students during their high school years have been extensively researched (Alexander \& Twinomurinzi, 2012; Cohen \& Parsotam, 2010; Seymour et al., 2005). Yet, not much research has been conducted after students have arrived at university and, to our knowledge, no study has looked at the sequence of events.

While strategies to attract students to a particular major might prompt students to change major (Downey et al., 2011), this has not been researched. Studying the events and experiences that influence students to change their majors is different to studying initial career choice. Firstly, much of the research on perceptions is based on pupil misperceptions and lack of access to technology. Yet, once students have completed their first year at university and a mandatory computing course, these misperceptions should have been addressed, and, considering that universities give all students equal access to technology, lack of technology should play a lesser role. Secondly, there might be experiences and events in their current major that are negative and drive career choice. Thirdly, experiencing structural constraints and the risk and resistance that comes with change might play a factor. Finally, prior studies have not considered the events that students undergo in the process of 
changing major. Therefore the research question posed is "what are the events that lead university students to change their major to IS?"

\section{THE CONTEXT AND THE CASE OF UCT}

Previous researchers have argued that career choice factors are complex and inter-related and need in-depth exploration. Hence, this research aimed to determine why students change their major to IS after their first year at university. The context for this study is higher education in South Africa.

South African universities face growing diversity in the student body resulting from massification and transformation in higher education (Smit, 2012). They are deeply affected by the same educational inequalities and poor educational performance that characterise the school system (Fisher \& Scott, 2011). Hence there are a growing number of students entering universities with inadequate schooling and without the necessary literacy, numeracy and academic skills crucial to succeeding in higher education. Universities are underprepared for meeting the needs of this changing student body (Smit, 2012) and therefore universities have high attrition rates especially amongst African students (Scott, Yeld, \& Hendry, 2007). High dropout and attrition rates and poor academic performance in the school system has also resulted in low relative participation rates in higher education (Fisher \& Scott, 2011) despite massification.

South African universities are also under funded by the state in comparison to other African universities; the government funding has not kept up with inflation and the increase in student numbers (Jones, 2015). This has resulted in rising fees, reduced access for poor students and recent violent student protests.

Most universities in Sub Saharan Africa have limited infrastructure such as internet access, bandwidth, hardware and software provision and unreliable access to electricity which impacts teaching technology (Sife, Lwoga, \& Sanga, 2007) and South Africa is not immune to these challenges which impacts computing education. These challenges might become more pronounced as the pressure to contain student fees increases.

The case was the University of Cape Town's commerce faculty. This single interpretive case study was chosen for this research because it enabled a deep exploration into individuals and their behaviour, and can be used to generalise findings and develop theory (Flyvbjerg, 2006).

In this case, students do have to choose a major when arriving, yet, with the exception of computer science and actuarial science, they can change their major at the end of their first year without extending the length of their degree. For majors which include IS, Accounting, Economics, Finance, Marketing and Organisational Psychology, the first year of studies is generic and is referred to as the 'common first year. The common first year courses include Accounting, Economics, Business Law, Mathematics, Statistics, Evidence Based Management and IS. Therefore, while in this study we have described reasons for students to change their major, in some cases students could merely be delaying their choice of major.

The introductory first year IS course focuses on students' understanding IS within organisations as well as their broader impact. In addition, students are introduced to computational thinking techniques used in software engineering; get to analyse data using Microsoft Excel; and begin to 
design and implement simple applications using programming languages such as Scratch and Android App Inventor (University of Cape Town, 2015). The role of IS in organisations, IS professional roles, and average salaries are presented in the course. The course has active online forum discussions and is convened by a female academic who is a strong role model and a vibrant lecturer. Hence, this course should address the possible misperceptions students have of the relevant computing disciplines.

\section{RESEARCH METHOD}

After ethics approval from the University, a list of students in the Commerce faculty who had transferred into or out of the IS major during 2014 was obtained from the Student Records Office. An aggregated version is presented in Table 1.

Table 1: List of students transferring into or out of an IS major in Commerce, UCT, 2014

\begin{tabular}{l|lll} 
Other major & $\begin{array}{l}\text { Into IS in good } \\
\text { academic standing }\end{array}$ & $\begin{array}{l}\text { Into IS with } \\
\text { readmission concession }\end{array}$ & $\begin{array}{l}\text { Out of IS in good } \\
\text { academic standing }\end{array}$ \\
\hline Accounting & 6 & 1 & 1 \\
Finance \& Tax & 2 & 1 & 1 \\
$\begin{array}{l}\text { Actuarial Science } \\
\text { Computer Science }\end{array}$ & 1 & 2 & 1 \\
$\begin{array}{l}\text { Marketing } \\
\text { Management studies }\end{array}$ & 1 & 1 & \\
$\begin{array}{l}\text { Construction } \\
\text { Economics / }\end{array}$ & 1 & & 3 \\
Economic History & 2 & & \\
Geomatics & & & 7 \\
\hline Grand total & 13 & 5 & 7
\end{tabular}

Of the 18 students that transferred in, the most common prior majors were Accounting (6 students) and Finance ( 3 students). The researcher sent an individual email to all 18 students inviting them for an interview. The research questions and themes from the literature formed the basis for the interview questions although they were modified during the interview based on student's responses. The interview guide listed in Table 2.

Three students had subsequently changed majors again or left the faculty leaving 15 students to interview. Semi-structured interviews (Myers \& Newman, 2007) were conducted with the 8 students who responded (53\% response). The students interviewed are listed in Table 3 with their demographic information. Only one female student was interviewed. In terms of race there was a balanced spread with 3 Black, 2 Indian, 2 White and 1 Coloured student interviewed. Two of the students were registered in the Academic Development (ADP) cohort. These students were identified as underprepared academically for university and were given extra support. Most students in this 
Table 2: Interview guide

\begin{tabular}{l}
\hline Subjective norm factors \\
• Did you study IT or CAT at high school and if not why? \\
- Since you didn't have access to technology in high school, now that \\
you do, why did you choose not to study IS? \\
• Did you consult a student advisor/lecturer about your decision to \\
change major? Why? \\
• Do you have access to computers at home? \\
• For how long before university have you had access to a computer at \\
home? \\
• Are parents part of the reason why you chose IS? \\
• What did you think of the introductory course? \\
- What IS related knowledge did you have before taking the introduc- \\
tory course? \\
- What is your perception/attitude on IS careers? \\
\hline - What outcomes do you expect to achieve from studying IS as a major? \\
• Did you choose this major based on salary, job availability, social \\
status, etc.?
\end{tabular}

cohort are from a financially disadvantaged background. All students had been at the university for at least two and a half years at the time of the interview and hence were able to talk to their experiences from a rich and considered perspective.

Multiple approaches were used for the research. Retroduction was used as it seeks to explain sequences of events by postulating and identifying mechanisms which are capable of producing them (Downward \& Mearman, 2006; Zachariadis, Scott, \& Barrett, 2013). As part of the retroductive approach, students were asked to describe the sequence of experiences and events that transpired before they changed their major. An inductive approach was also used. Some factors which students considered when changing to IS as a major confirmed some of the prior theoretical models and, therefore, this research also had elements of deduction. Thematic analysis was used to analyse the data inductively and deductively (Braun \& Clarke, 2006). Thematic analysis enables reporting on people's experiences, perspectives and meanings whilst examining the ways in which events, realities, 
meaning and experiences come about Braun and Clarke, 2006.

Table 3: List of research participants

\begin{tabular}{l|lll} 
Interview code & Demographic & Year changed to IS & Previous major \\
\hline I1 & Black Male & Second & Accounting \\
I2 & Black Male (ADP) & Second & Accounting \\
I3 & Indian Male & Third & Computer and Electrical Engineering \\
I4 & Black Male & Third & Computer Science \\
I5 & White Male & Third & Accounting \\
I6 & Indian Female & Second & Actuarial Science \\
I7 & White Male & Third & Marketing \\
I8 & Coloured Male (ADP) & Second & Accounting
\end{tabular}

The retroductive analysis for each interview focused on the core sequence of events and experiences that led to a student changing their major to IS. While a student might have referred to many themes, only the dominant ones and in the correct sequence were selected. In the paragraphs below and in Figure 1 and 2, the retroductive analysis for I1 and I2 is presented.

I1 chose his major because "accounting is very prestigious and a lot of people go for accounting apparently it's well-paying." Furthermore, his father was in the accounting profession, so he chose accounting because it was familiar to him. Before he arrived at university, he had no information regarding IS. After he arrived at University, he found accounting boring and wanted to pursue his interest in IS because he "enjoyed working on computers." He enjoyed the introductory course and was inspired by the "success stories and innovative IT stories pertaining to the relevance of IT." Afterwards, he researched possible career paths and decided at the beginning of his second year to change to IS.

I2 had no prior information regarding what IS was. He thought "IS was computer science and very technical and I didn't know UCT offered IS" even though he studied computing at high school. When he arrived at UCT and enrolled in the introductory course IS, he did not like the way IS was portrayed. I2's reason for initially considering changing majors stemmed from his loss of passion for his previous major. He found Accounting tedious and because he did not want to become a programmer, he searched for available options and finally settled with IS because it is not too technical. He stressed that he was a very commerce-oriented person and, in his decision to change majors, it was critical that he was in the Commerce Faculty because he wanted to learn about business. In order to reach his decision, he talked to previous IS graduates and looked at the Commerce Faculty Handbook to evaluate what was necessary when changing majors. He expressed that other graduates, "gave me a hands on what the projects are about, what they do in final year, how they structure the degree, what IS is." He felt unsure about his decision to change and felt it was a great gamble to change majors. He went on further to express that

So I took a very objective point of view, what can I do and I think after second year. It was pretty open, it wasn't like ok no I'll start from scratch to do an IS degree. Some of the stuff counted, some of the stuff didn't. [I2] 


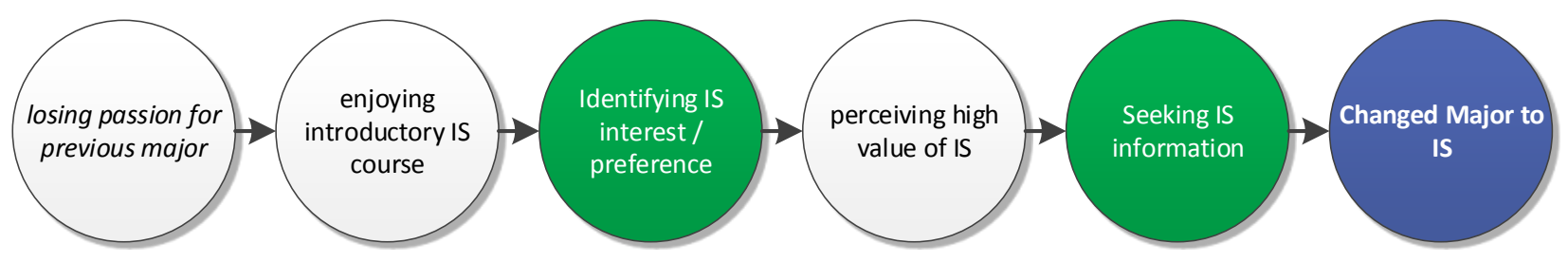

Figure 1: Retroductive analysis for I1

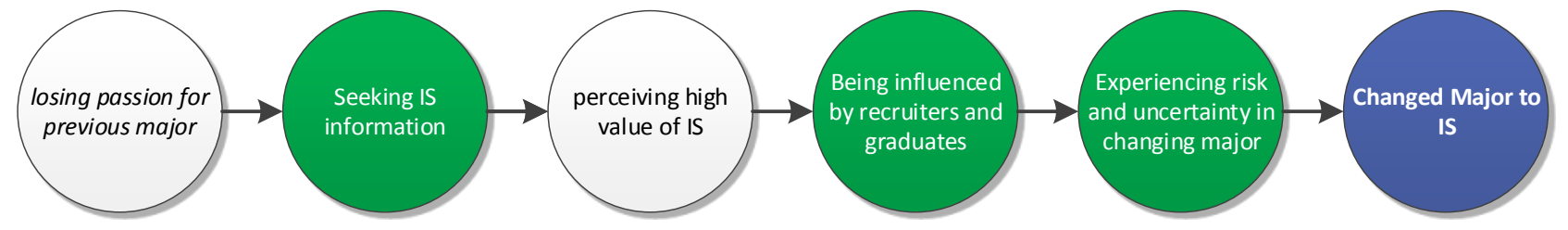

Figure 2: Retroductive analysis for I2

\subsection{Limitations}

Eight interviews is deemed to be sufficient for qualitative analysis as rich feedback was obtained. However, more responses would have been preferred and theoretical saturation was not reached. This is a limitation.

A second limitation to this study is that not all students who were invited to participate responded and this could have introduced a self-selection bias. Finally the sample had one female and, therefore, factors influencing female students would be under-represented. This is of concern because of the gender imbalance and research which confirms differences in perceptions of computing careers across gender (Zafar, 2013).

\section{PERCEPTIONS FROM HIGH SCHOOL STILL PREVALENT AT UNIVERSITY}

The assumption made at the start of this research was that misperceptions of majors would have been resolved by the end of a student's first year at university and that students would have relatively equal access to technology provided by the university and have experienced improved computer efficacy by completing the introductory IS course. Yet students are reluctant to change majors and it became apparent in this research that misperceptions which were prevalent in high school still affected interviewees. These perceptions were dominated by misperceptions of the value of IS and a lack of IS information.

The comments by the students showed that they were not previously exposed to IS and, hence, this was why they did not initially choose IS. What was also revealed was that IS was not mentioned by teachers nor advertised in high school recruitment. This resulted in misperceptions of the major. 
Teachers would tell people ... IS wasn't really explained what it was about so I didn't really know what it was about. [I8]

I feel like a lot of people come from backgrounds like they only choose to do what they have been exposed to and have heard about. Too few people have heard about IS and so more people choose other B.Com. degrees. [I1]

Students expressed that their view of IS was skewed based on the information they received prior to university and based on what they saw at high school. Three misperceptions prevalent at high school were confirmed. Firstly, pupils are not aware that there are skills shortages in computing fields and, in fact, one student had a misperception that there were no jobs in IS. Secondly, the misperception exists that accountants earn substantially more than IS professionals. Finally, the misperception exists that IS is predominantly technical, this has been noted in the literature (Cheryan et al., 2013).

I wanted to do IS when I was young but in my country (France) I was told that there were not enough jobs. I realise now after a few years that it is actually the opposite. [I7]

I did accounting because of my parents, accounting is very like prestigious, [inaudible] ... a lot of people go for accounting apparently it's well-paying. [I2]

Teachers would tell people 'CA are the way to go, it has the most money'. [I8]

I thought IS was computer science and very technical and I didn't know [the university] offered IS. [I2]

In the Commerce Faculty, the introductory IS course did provide students with information on IS so some misperceptions were resolved for some students.

I knew how to work a computer but I learnt most of the IS knowledge once I got to university and studied IS1. [I5]

\section{EVENTS AT UNIVERSITY LEADING TO CHANGING MAJOR}

Considering the reluctance to change majors, the events that contributed to students changing their major to IS were considered. As part of the inductive analysis, 11 core themes emerged which are presented in Table 4. The number of empirical observations or text extracts which were counted for each theme are also presented. This section includes the analysis and discussion as the linkage with theory for each factor analysed is also discussed.

The relevant ranking of each theme was determined by the count of observations for the theme as well as the importance that interviewees gave to the theme. The numbered sequence of events leading to each respondent changing their major to IS is shown in the retroductive analysis columns in Table 4 and is presented graphically in Figure 3. Dominant events are in bold font. Events which initiated the process of changing major are depicted in italicised font. Events which preceded the event of actually changing major to IS are shown in shaded circles in Figure 3 . In the following section, each theme will be discussed following its general sequence in the retroductive analysis. 
Table 4: Result of inductive and retroductive analysis

\begin{tabular}{|c|c|c|c|c|c|c|c|c|c|c|}
\hline \multirow[b]{2}{*}{ Events } & \multicolumn{2}{|c|}{ Inductive analysis } & \multicolumn{8}{|c|}{ Retroductive analysis } \\
\hline & Count & Rank & I1 & $\mathrm{I} 2$ & I3 & I4 & I5 & I6 & I7 & I8 \\
\hline Losing passion for previous major & 11 & 3 & 1 & 1 & 1 & & 1 & 1 & & 1 \\
\hline $\begin{array}{l}\text { Experiencing difficulty with } \\
\text { previous major }\end{array}$ & 4 & 8 & & & & & & & 1 & 2 \\
\hline Enjoying introductory IS course & 8 & 5 & 2 & & 2 & 1 & & 2 & & \\
\hline Considering alternate options & 6 & 6 & & & & & & & 2 & \\
\hline $\begin{array}{l}\text { Performing well in introductory } \\
\text { IS course }\end{array}$ & 5 & 7 & & & 3 & 2 & & 3 & 4 & \\
\hline Seeking IS information & 9 & 4 & 5 & 2 & 5 & 4 & 2 & 4 & 3 & 3 \\
\hline $\begin{array}{l}\text { Experiencing risk and uncertainty in } \\
\text { changing major }\end{array}$ & 2 & 11 & & 5 & & & 3 & & & \\
\hline Perceiving high value of IS & 15 & 1 & 4 & 4 & 4 & 3 & & 5 & & \\
\hline Identifying IS interest / preference & 11 & 2 & 3 & & & 5 & & & & \\
\hline $\begin{array}{l}\text { Experiencing restrictions on choice } \\
\text { of major / courses }\end{array}$ & 4 & 10 & & & & & & 6 & & 4 \\
\hline $\begin{array}{l}\text { Being influenced by recruiters and } \\
\text { graduates }\end{array}$ & 5 & 9 & & 3 & & & & & & 5 \\
\hline
\end{tabular}

\subsection{Losing passion for previous major}

The second most dominant factor based on the number of empirical observations and the most dominant initiating factor was losing passion for previous major. Students are reluctant to change their initial major and it seems that the dominant driver is a negative experience with their major as opposed to a positive experience with another potential major, 7 out of the 8 students who transferred into IS stated that the loss of passion for their previous major made them rethink their major:

I just lost the passion for it I guess, I didn't have the drive to study and continue with it. [I5]

I thought I liked accounting, but then I discovered that not really. You understand it but then I was like no I need to pursue something that I enjoy. [I6]

A student's passion for their major is said to be reflected in their educational and professional aspirations (Noble \& Childers, 2008). Research has indicated that students primarily lose interest because of a lack of mentors, role models, and career guidance (Reck, Stratman, Vogel, \& Mukesh, 2006). In contrast, students in this research lost their drive for their previous major because of not enjoying the first year course in their major. This experience ties in with the TRA concept of experiential belief but is otherwise not in the literature. 


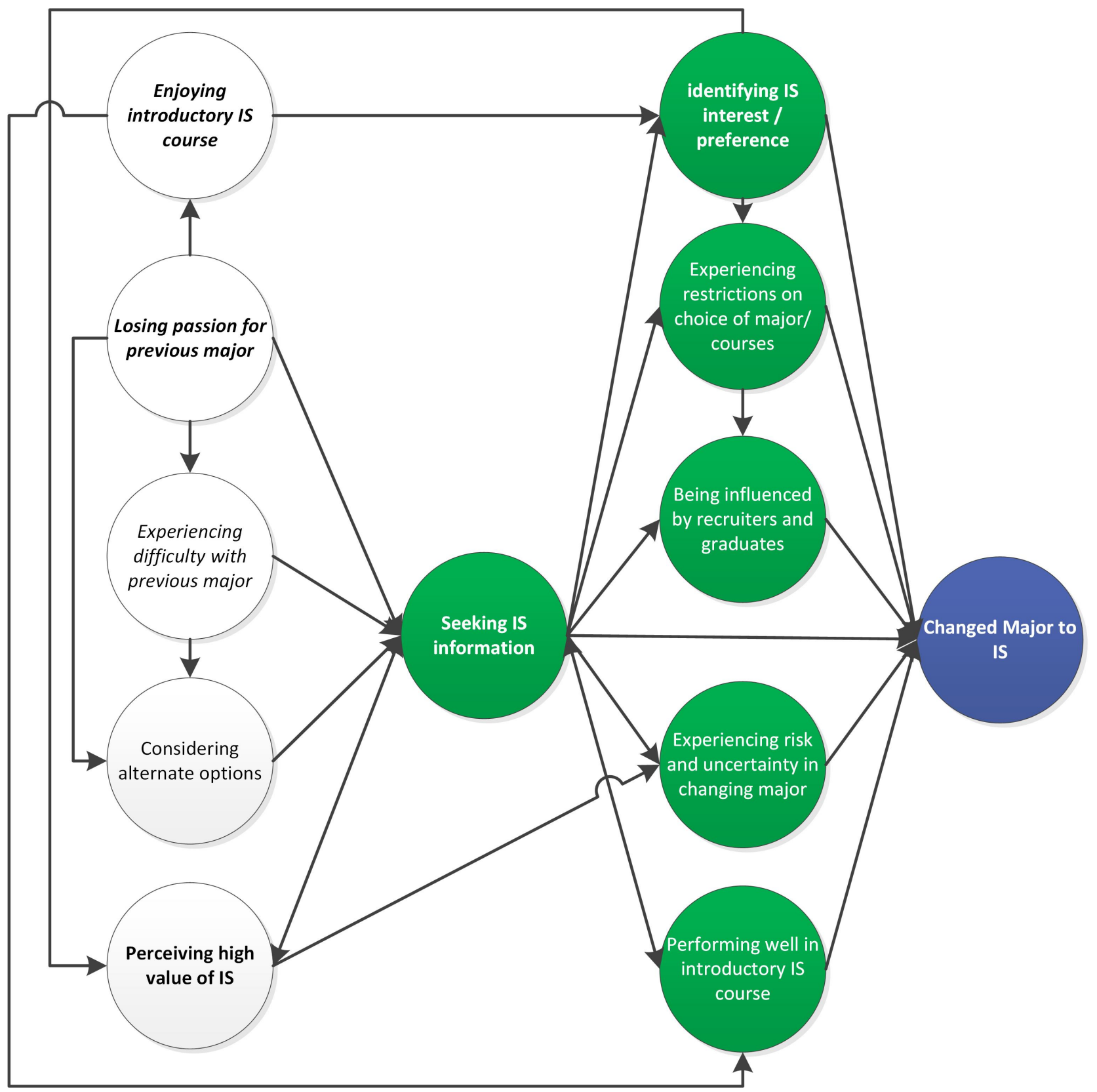

Figure 3: Sequence of factors affecting students changing to IS at university 


\subsection{Experiencing difficulty with previous major}

Experiencing difficulty with a major was identified as a significant factor contributing to students' changing major and was the initiating factor for one student. Students expressed that the requirements for their previous majors were too high to fulfil or that they were just not coping academically. Sometimes this leads to changing degrees as was the case with the students who changed to IS quoted here:

Also the requirements for actuarial sciences were high and economics was giving me a problem also. [I6]

I was failing. IS was kind of a backup plan but at the same time I still think it's interesting. [I7]

Difficulty with a major can be linked to students' learning styles, their approach to learning, and their orientations to studying and intellectual development Felder and Brent, 2005. Difficulty with a major can cause students to reassess their academic standing and investigate steps to ensure that they are able to fulfil degree requirements. Ability to do course work has been shown to be an influencing factor on career choice (Arcidiacono et al., 2012). Research using TRA has mentioned difficulty of major as an experiential belief influencing career choice (Downey et al., 2011). SCCT research has also referred to subject self-efficacy concerns (Alexander \& Twinomurinzi, 2012).

\subsection{Enjoying introductory IS course}

Enjoying the introductory IS course was ranked fifth in the list of experiences and events leading to students changing to IS; it was essential to the change and was the initiating factor for one student. The students' enjoyment also appeared to directly influence academic performance in the introductory IS course and sparked interest in the IS major. Enjoyment is an intrinsic value and has a direct influence on intention to study using online resources (Chen, Lin, Yeh, \& Lou, 2013). Enjoyment can be based on the experience that students have working with computers (Chen et al., 2013). The following statements confirm the importance of enjoyment.

When I did IS 1 I really enjoyed that. I enjoyed the part where you just got use computers. [I1]

I got a laptop in first year, whenever I talk about computer related stuff with friends, or watch computer related stuff or coding, the concepts I find them fascinating and I want to learn all of them. [I8]

Enjoying the first year introductory course is an important finding; students perceive that if they enjoy a course they would enjoy a career in that field. While enjoyment is not included in any career choice theories, it would be classified as an experiential belief in TRA. 


\subsection{Considering alternate options}

Searching for alternate options was ranked 6th in this study and does not appear in career choice theory or the literature. It often followed from students struggling academically in their initial major. Career choice can be linked to available options because students chose careers that they have been exposed to and have self-efficacy. Some students referred to IS as not their first choice but, due to their performance in their first choice or due to curriculum constraints in terms of changing to their best choice, they chose it as their alternate option as quoted here:

I was like I need courses and subjects and took up the next IS courses and kind of forced myself through it and started liking it and saw its value. [I3]

Mainly UCT with the concession [the student was given a concession to remain at UCT but needed to change their major], I didn't really have a choice. It's a good thing; I think it was destiny (God-willing). [I7]

And to transfer into engineering is too hard and it's not like I am saying IS is my second option ... it just seemed more fitting what I want from IT. [I2]

\subsection{Performing well in introductory IS course}

Students are more likely to develop interests in a computing major when they feel confident about their capabilities to succeed (Akbulut \& Looney, 2007). This factor dominates in the literature and is referred to as aptitude in major according to TRA and self-efficacy in major/career in SCCT (Alexander \& Twinomurinzi, 2012; Bandura, 2012). In this study, the realisation that IS was a good option was through academic performance in the introductory course. This theme mostly followed enjoying the introductory IS course. Some students even found that they performed better in the introductory IS course than in their majors:

I was top of class and I got medals at it. [I3]

In terms of my thinking, it worked better in CS than economics and accounting. I got 75\%. [I6]

It was actually my best, I got $72 \%$. That's why I wanted to do IS after marketing because I was getting 40 s and $42 \%$ but I got $72 \%$ for IS. [I7]

\subsection{Seeking IS information}

Seeking information about IS through personal research and sources of information regarding IS played an influencing role in the process of changing to IS for all respondents. All students did some personal research to gain understanding of IS before changing majors. Sometimes it led to directly changing majors but it also led to unearthing risk and uncertainty or curriculum restrictions. It was ranked as the fourth most important factor but is not explicitly included in any career choice theory. The sources of information regarding IS included the Faculty handbook. Quoting three respondents: 
I had taken all of the courses in first year and second year which is very generic to any degree and then I was like ok, I made out all of the possible degrees I can do, so took a very objective point of view. [I2]

So I was looking at what I could take and what would interest me. Then I saw IS and CS in the booklet so I planned on changing to that and they said I could only take IS which was fine. [I8]

I knew one guy who did accounting with me then switched to IS. Yeah but mostly my research. [I5]

Students are known to seek information before making a decision about selecting a major. Previous research focussed on the seeking process prior to university where sources of information regarding choice of major include family experiences of higher education and information sharing between students, families, high schools and universities (Mao, 2013). The seeking process does not explicitly form part of either SCCT or TRA theories.

\subsection{Experiencing risk and uncertainty in changing major}

Students mentioned feelings of unease when deciding to change majors. 14 stated that even with all the information obtained regarding IS, he still felt unsure about his decision to change majors. I2 stated that he felt that it was a gamble to change majors and it was not a decision he took lightly when considering changing majors:

Also like it was a bit of a gamble to change to something you don't know what it is, you are gambling quite a lot changing a major, this is not like changing a course or dropping something. [I2]

Students who register for courses expect the benefits of the course to exceed the costs of completing the course (Bosshardt, 2004). Yet this uncertainty does not form part of any theory on career choice. Students wanting to change majors faced this dilemma of evaluating whether it would be worth changing major or not. This is linked to the risk and uncertain feeling they felt because they were unsure of the outcomes.

\subsection{Perceiving high value of IS}

Perceiving high value of IS was ranked as the dominant factor and had the highest count of empirical observations. The perceived value of IS can be linked to outcomes such as future salary and high job prospects, that students hope to achieve in their career. Furthermore, students said they valued the team based work environment offered by IS jobs over 'desk jobs offered by their previous majors.

I know there are a lot of job opportunities that are open for graduates. [I6]

I noticed I can make a lot of money if I go through this route and learn a lot about business. [I3] 
The interest for IS came from the role that I could take with IS, that's the interest came not that I was good at computers or something ... The role that it occupies in the world. [I4]

IS gave me knowledge of more teamwork based, project management, just more collaboration. [I5]

Inspiration by future earnings is referred to as social and physical outcome expectations in SCCT (Cohen \& Parsotam, 2010; Downey et al., 2011). Job security and job availability refer to the ease with which students will obtain their first job after graduation and the availability of work throughout their careers; they are both dominant factors in TRA studies (Downey et al., 2011). Students have been reported to change majors because of the other attractions associated with the new major such as career possibilities, more interesting courses and available job openings in the field (Lastusaari \& Murtonen, 2013). Economic models of college choice refer to these factors as pecuniary outcomes such as social status, earning profile and likelihood of finding employment (Zafar, 2013).

\subsection{Identifying IS interest/preference}

Interest and preference for IS curricula was the third most dominant factor. All students said they chose IS because they had a preference and interest for the major and that they felt their skills were aligned with IS. This was different for each interviewee. What was consistent was that students wanted to work on computers and practical courses rather than theoretical courses. Furthermore, most students in the study preferred the team work provided by IS.

I have always been a technical person; I have enjoyed technology and information ... seems broader, more team work and less desk job. [I5]

I enjoyed the part where you just got to use computers and you didn't have to write. [I1]

Interest in IS can be linked to students' attitudes towards a certain major which is unique and individualistic. Interest in the IS field or major are dominant factors in both SCCT and TRA based studies. The importance of technical skills has been found to be higher for IS majors than for other business majors (Roach, McGaughey, \& Downey, 2011). Students who choose computing majors have been shown to have a preference for an experimental style of learning rather than more structured approaches prevalent in non-computing majors (Alexander, Pieterse, \& Lotriet, 2011). In this study, when choosing to change majors, students evaluated their interests. In this research, this experience is largely attributed to the introductory IS course. Introductory IS courses have not always aligned their curriculum and assessments with IS professional work and have often focused on computer literacy (Govender \& Naidoo, 2013). Hence, there have been calls for these courses to align important student preferences with the reality of an IS major and career (Ferratt et al., 2010).

\subsection{Experiencing restrictions on choice of major/courses}

Restrictions on choice of major relates to external influences such as faculty, bursars and course requirements. Students who are given bursaries or financial aid that are linked to certain majors 
or have restricted time periods are also known to be less likely to transfer majors; hence, financial aid reduces the flow of students between majors (Lassibille, 2011). It is evident that some students lacked options when changing their majors or even changing faculties:

In terms of my bursary, I have to let them know that I am changing from this degree to that and then they can approve it... Also they want you to change to a stream within the faculty so that you don't repeat a year or rather lose the courses you have done because they want the credits for the courses you have done from first year. [I6]

I wanted to study IS and computer science and they said I needed to study more maths to add to computer science so I decided to just study IS. [I8]

Institutional arrangements can allow or disallow a student to study certain majors due to pre-requisite courses. Requirements in certain majors cause students to re-evaluate their academic standing and options when changing majors. In this study, changing to IS after first year had relatively few consequences mostly because of the common first year. However, after that it increased the length of the degree:

Some of the stuff counted, some of the stuff didn't, some of the courses I put a lot of effort into didn't count and they don't give you credit, not like you can even get half. You lose out a bit. [I2]

This factor does not form part of studies using TRA or SCCT although CCM does refer to educational arrangements as a structural influence on career choice. A previous study did identify prerequisite courses as hindrances to students pursuing their choice of major and called universities to put education in the hands of students and to have less restrictive curricula and transfer rules (Riesen, 2011).

\subsection{Being influenced by recruiters and graduates}

In this study some students were influenced by IS postgraduate students and recruiters:

This IS guy who graduated in IS was recruiting people, not recruiting but advertising, talking about how he used to do something else but changed to IS and then he loved it because of the team projects and coding. [I8]

I was talking to a lady working in Foschini groups who said there are a lot of job opportunities. [I6]

My friends who studied IS. First they gave me a hands on what the projects are about, what they do in final year... I also talked to student advisors but they do it from a very like, this is how long it will take you not the context. [I2]

External recruiters at university career fairs are seen as a powerful influence because they are external and are perceived to have less bias than student advisors and lecturers. Recruiters show students that there are job opportunities, mention the nature of the work and focus on the relevance of the major. 
The importance of giving first year students access to graduates and recruiters has been stressed by (Whelan \& Firth, 2012). This influencing factor is seldom mentioned in studies using SCCT and TRA. In contrast, TRA studies have shown the influence of family and friends to dominate subjective norms (Downey et al., 2011).

\subsection{Discussion of resultant model}

This study confirms that some initial career choice factors influences students to change majors. Hence the use of SCCT and TRA was found to be useful in this research. Of the 11 dominant events, 8 events could be indirectly attributed to factors from these theories or at least classified according to constructs in these theories. The events and experiences that influenced students to change their major to IS are summarised in Table 5 and mapped to the relevant theories.

Confirming TRA and SCCT studies, self-efficacy/aptitude in the major, interest in the major and perceived value of the major were all dominant factors. In contrast to other studies, subjective norms that appear to influence students changing majors were the influence of graduates and recruiters. A dominant factor found in this study which is not included in current TRA and SCCT studies is the role of enjoying introductory courses and losing passion for previous majors during the first year at university. Socio-structural factors have been under-researched, and this study identified financial aid and course prerequisite constraints as well as the high risk and uncertainty as important factors preventing students from changing to their major of choice. Finally, this study looked at career choice from a retroductive perspective and was able to explain the sequence of experiences and events that students underwent when changing majors and, therefore, adds deeper understanding to this phenomena.

From a practical perspective, the findings of this paper suggest practical actions that universities can take to increase enrolments in misunderstood majors. Firstly, a generic first year for students is seen as critical, and administrative or funding barriers to students changing their major need to be reduced. Losing passion for a previous major is a strong driver for students changing their major and is a sign of an incorrect first choice. Universities need to increase awareness of this and offer more guidance counselling for high school pupils and also to students when they arrive at university.

To increase enrolments in IS, changes to the first year introductory IS course can be made as follows: Firstly, the course content needs to focus on skills more aligned to IS professional practices so students are able to identify with the relevant work interests and preference. Secondly, the value of IS needs to be conveyed in this course. Thirdly, the course needs to expose students to the perceptions of credible graduates and/or recruiters and finally, the course needs to be made more enjoyable and should not be harder than other first year courses. Yet this final action needs to be considered cautiously, taking into account unintended consequences. There would be negative value in alluring students into a major which might not suit them and which they might later regret. 
Table 5: Dominant events mapped to the literature

\begin{tabular}{|c|c|c|}
\hline Events & Factors in the literature & Theory category \\
\hline $\begin{array}{l}\text { Losing passion for } \\
\text { previous major }\end{array}$ & & TRA experiential belief \\
\hline $\begin{array}{l}\text { Experiencing } \\
\text { difficulty with } \\
\text { previous major }\end{array}$ & $\begin{array}{l}\text { Ability to do course work } \\
\text { (Arcidiacono, Hotz, \& Kang, 2012) } \\
\text { Aptitude in major (Downey, McGaughey, \& } \\
\text { Roach, 2011) } \\
\text { Difficulty of major (Downey, McGaughey, \& } \\
\text { Roach, 2011) } \\
\text { Subject self-efficacy } \\
\text { (Alexander \& Twinomurinzi, 2012) }\end{array}$ & $\begin{array}{l}\text { TRA experiential belief } \\
\text { SCCT self-efficacy }\end{array}$ \\
\hline $\begin{array}{l}\text { Enjoying introductory } \\
\text { IS course }\end{array}$ & $\begin{array}{l}\text { Enjoying course work (Zafar, 2013) } \\
\text { Perceived enjoyment influences intention to } \\
\text { use e-learning (Chen, Lin, Yeh, \& Lou, 2013) }\end{array}$ & TRA experiential belief \\
\hline \multicolumn{3}{|l|}{$\begin{array}{l}\text { Considering alternate } \\
\text { options }\end{array}$} \\
\hline $\begin{array}{l}\text { Performing well in } \\
\text { introductory IS } \\
\text { course }\end{array}$ & $\begin{array}{l}\text { Ability to do course work } \\
\text { (Arcidiacono, Hotz, \& Kang, 2012) } \\
\text { Subject self-efficacy } \\
\text { (Alexander \& Twinomurinzi, 2012) }\end{array}$ & \\
\hline $\begin{array}{l}\text { Seeking IS } \\
\text { information }\end{array}$ & $\begin{array}{l}\text { Seeking process prior to university } \\
\text { (Mao, 2013) }\end{array}$ & \\
\hline $\begin{array}{l}\text { Experiencing risk and } \\
\text { uncertainty in } \\
\text { changing major }\end{array}$ & $\begin{array}{l}\text { Benefits of a course needs to exceed the costs } \\
\text { of completing the course (Bosshardt, 2004) }\end{array}$ & \\
\hline $\begin{array}{l}\text { Perceiving high value } \\
\text { of IS }\end{array}$ & $\begin{array}{l}\text { Status (Alexander \& Twinomurinzi, 2012) } \\
\text { Pecuniary outcomes (Zafar, 2013) } \\
\text { Social image of major and job } \\
\text { availability (Downey, McGaughey, \& Roach, } \\
\text { 2011) }\end{array}$ & $\begin{array}{l}\text { SCCT outcome expectations } \\
\text { TRA normative belief }\end{array}$ \\
\hline $\begin{array}{l}\text { Identifying IS interest } \\
\text { / preference }\end{array}$ & $\begin{array}{l}\text { Interest in the IS field (Downey, McGaughey, } \\
\text { \& Roach, 2011) } \\
\text { Interest in major } \\
\text { (Alexander \& Twinomurinzi, 2012) } \\
\text { Preference for work } \\
\text { (Arcidiacono, Hotz, \& Kang, 2012) }\end{array}$ & $\begin{array}{l}\text { SCCT interest } \\
\text { TRA normative belief }\end{array}$ \\
\hline $\begin{array}{l}\text { Experiencing } \\
\text { restrictions on choice } \\
\text { of major / courses }\end{array}$ & $\begin{array}{l}\text { Financial aid constraints (Lassibille, 2011) } \\
\text { Prerequisite courses (Riesen, 2011) }\end{array}$ & CCM Structural Factors \\
\hline $\begin{array}{l}\text { Being influenced by } \\
\text { recruiters and } \\
\text { graduates }\end{array}$ & $\begin{array}{l}\text { Access to graduates and recruiters } \\
\text { (Whelan \& Firth, 2012). }\end{array}$ & $\begin{array}{l}\text { SCCT sources of outcome expec- } \\
\text { tations } \\
\text { TRA Subjective Norm }\end{array}$ \\
\hline
\end{tabular}




\section{CONCLUSION}

Limited increases in computing discipline enrolments are problematic when there is a simultaneous rise in demand for ICT professionals. Research has shown that the IS discipline is misunderstood by pupils in high school which contributes to low enrolment at university. In this case study in the Commerce faculty of UCT, we researched students changing their major to IS after their first year of university. We argue that, after one year at university, misperceptions from high school should have been addressed. This retroductive analysis investigated the relevant experiences and events at university that drive students to change their major to IS. The two dominant factors were the perceived high value of IS and a preference for IS. These factors are aligned with social and physical outcome expectations, and interest, respectively, in Social Cognitive Career Theory. Yet neither of these factors were the initial cause of students considering the change.

In this case, the initial events prompting changing a major include a loss of passion or difficulty in a current major and enjoying an alternate introductory course. These events can be generalised outside of this case setting and to other majors; hence, this research is of theoretical relevance as it adds to the literature on factors influencing career choice in general. The experience of students in first year courses needs to be aligned with the experiences that professionals would face in their work environment; this would lead students with a preference for and interest in a particular discipline or career to more easily identify with that preference during the introductory course.

These findings provide an initial practical guide for universities. However the recommendations given need to be considered in terms of the small and male skewed sample in this study. Further research is needed as this research only looked at a small facet of a broader field. What would be the unintended consequences of these suggested actions? What other factors can influence students to change their majors? How many students graduate in majors that they later regret? These are all questions worthy of future research.

\section{References}

Adya, M. \& Kaiser, K. M. (2005, September). Early determinants of women in the IT workforce: a model of girls' career choices. Information Technology \& People, 18(3), 230-259. http://dx.doi. org/10.1108/09593840510615860

Akbulut, A. Y. \& Looney, C. A. (2007, October). Inspiring students to pursue computing degrees. Communications of the ACM, 50(10), 67-71. http://dx.doi.org/10.1145/1290958.1290964

Alexander, P. M., Pieterse, V., \& Lotriet, H. (2011). A comparison of computing and non-computing students' personalities based on the five-factor model. In 2011 Proceedings of the European Conference on Information Systems (ECIS). Retrieved from http://aisel.aisnet.org/cgi / viewcontent.cgi?article $=1053 \&$ context $=$ ecis 2011

Alexander, P. M. \& Twinomurinzi, H. (2012). Changing career choice factors as the economic environment changes. In Proceedings of the south african institute for computer scientists and information technologists conference - SAICSIT '12. Association for Computing Machinery (ACM). http://dx.doi.org/10.1145/2389836.2389872 
Arcidiacono, P., Hotz, V. J., \& Kang, S. (2012, January). Modeling college major choices using elicited measures of expectations and counterfactuals. Journal of Econometrics, 166(1), 3-16. http://dx.doi.org/10.1016/j.jeconom.2011.06.002

Bandura, A. (2012). On the functional properties of perceived self-efficacy revisited. Journal of Management, 38(1), 9-44. http://dx.doi.org/10.1177/0149206311410606. eprint: http://jom.sagepub.com/content/38/1/9.full.pdf+html

Bosshardt, W. (2004, April). Student drops and failure in principles courses. The Journal of Economic Education, 35(2), 111-128. http://dx.doi.org/10.3200/JECE.35.2.111-128

Braun, V. \& Clarke, V. (2006). Using thematic analysis in psychology. Qualitative Research in Psychology, 3(2), 77-101. http://dx.doi.org/10.1191/1478088706qp063oa. eprint: http://www. tandfonline.com/doi/pdf/10.1191/1478088706qp063oa

Breytenbach, J. (2013). A critical review of ICT-enabled development influencing the quality and quantity of South African tertiary education students (Doctoral dissertation, University of Pretoria). Retrieved from http://www.repository.up.ac.za/handle/2263/32046

Calitz, A. P., Greyling, J. H., \& Cullen, M. D. M. (2011). ICT career track awareness amongst ICT graduates. In Proceedings of the south african institute of computer scientists and information technologists conference on knowledge, innovation and leadership in a diverse, multidisciplinary environment - SAICSIT '11. Association for Computing Machinery (ACM). http://dx.doi.org/ $10.1145 / 2072221.2072229$

Chakabuda, T. C., Seymour, L. F., \& van der Merwe, F. I. (2014, May). Uncovering the competency gap of students employed in business process analyst roles-An employer perspective. In 2014 IST-Africa Conference Proceedings. Institute of Electrical \& Electronics Engineers (IEEE). http://dx.doi.org/10.1109/ISTAFRICA.2014.6880599

Chen, Y.-C., Lin, Y.-C., Yeh, R. C., \& Lou, S.-J. (2013, April). Examining factors affecting college students' intention to use web-based instruction systems: Towards an integrated model. Turkish Online Journal of Educational Technology (TOJET), 12(2), 111-121. Retrieved from http: //eric.ed.gov/?id=EJ1015419

Cheryan, S., Plaut, V. C., Handron, C., \& Hudson, L. (2013). The stereotypical computer scientist: Gendered media representations as a barrier to inclusion for women. Sex Roles, 69(1), 58-71. http://dx.doi.org/10.1007/s11199-013-0296-x

Cloete, E. (2011). Business students' perceptions of information systems and electronic commerce. In A. Koch \& P. van Brakel (Eds.), Proceedings of the 13th Annual Conference on World Wide Web Applications, Johannesburg, 14-16 September 2011. Retrieved from http://www.zaw3.co.za/ index.php/ZA-WWW/2011/paper/viewFile/495/137

Cohen, J. F. \& Parsotam, P. (2010). Intentions to pursue a career in Information Systems and Technology: An empirical study of South African students. In Key competencies in the knowledge society (pp. 56-66). Springer Science + Business Media. http://dx.doi.org/10.1007/978-3642-15378-5_6

Croasdell, D., McLeod, A., \& Simkin, M. G. (2011). Why don't more women major in information systems? Information Technology \& People, 24(2), 158-183. 
de Villiers, C., Johnson, R., \& Cremer, P. (2012). South African ICT Skills deficiency. In AMCIS 2012 Proceedings. Retrieved from http:/ / aisel . aisnet.org/amcis2012 / proceedings / ICTinGlobalDev/16

Deloitte South Africa. (2014). South Africa ICT skills shortage starts in Matric. Last accessed 29 Jun 2016. Retrieved from http://www.deloitteblog.co.za/south-africa-ict-skills-shortagestarts-in-matric/

Downey, J., McGaughey, R., \& Roach, D. (2011, January). Attitudes and influences toward choosing a business major: The case of Information Systems. Journal of Information Technology Education: Research, 10(1), 231-251. Retrieved from https://www.learntechlib.org/p/111520

Downward, P. \& Mearman, A. (2006, March). Retroduction as mixed-methods triangulation in economic research: Reorienting economics into social science. Cambridge Journal of Economics, 31(1), 77-99. http://dx.doi.org/10.1093/cje/bel009

Felder, R. M. \& Brent, R. (2005). Understanding student differences. Journal of Engineering Education, 94(1), 57-52. http://dx.doi.org/10.1002/j.2168-9830.2005.tb00829.x

Ferratt, T. W., Hall, S. R., Prasad, J., \& Wynn, D., Jr. (2010). Choosing Management Information Systems as a major: Understanding the smiFactors for MIS. Communications of the Association for Information Systems, 27(16). Retrieved from http://aisel.aisnet.org/cais/vol27/iss1/16

Finnie, R. \& Norrie, K. (2013). ICT skills shortages: Framing the issues. Last accessed 29 Jun 2016. Retrieved from http://www.voced.edu.au/content/ngv\%3A60209

Fisher, G. \& Scott, I. (2011, October). Background paper 3: The role of higher education in closing the skills gap in South Africa. The World Bank Human Development Group. Last accessed 29 Jun 2016. Retrieved from http://glenfisher.ca/downloads/files/Higher\%20Education\% 20in\%20SA.pdf

Flyvbjerg, B. (2006). Five misunderstandings about case-study research. Qualitative inquiry, 12(2), 219-245. http://dx.doi.org/10.1177/107780040528436

Galpin, V. C. \& Sanders, I. D. (2007, December). Perceptions of computer science at a South African university. Computers \& Education, 49(4), 1330-1356. http://dx.doi.org/10.1016/j. compedu.2006.02.008

Govender, I. \& Naidoo, E. (2013, December). Perceived relevance of an introductory information systems course to prospective business students. South African Computer Journal, 51, 1-9. http://dx.doi.org/10.18489/sacj.v51i0.164

Hendriks, C. (2013). Integrated financial management information systems: Guidelines for effective implementation by the public sector of South Africa: Original research. South African Journal of Information Management, 15(1), 1-9. Retrieved from http://reference.sabinet.co.za/ document/EJC131473

Jones, R. (2015, December). A right to knowledge. Journal of the Southern African Institute of Mining and Metallurgy, 115(12). Retrieved from http://www.scielo.org.za/scielo.php?pid=S0038$223 \times 2015001200002 \&$ script $=$ sci_arttext\&tlng=es

Kuo, F.-Y., Tseng, F.-C., Lin, C. I., \& Tang, W.-H. (2013, September). Critical success factors for motivating and sustaining women's ICT learning. Computers \& Education, 67, 208-218. http: //dx.doi.org/10.1016/j.compedu.2013.03.006 
Lassibille, G. (2011). Student progress in higher education: What we have learned from large-scale studies. The Open Education Journal, 4, 1-8. http://dx.doi.org/10.2174/1874920801104010001

Lastusaari, M. \& Murtonen, M. (2013). University chemistry students' learning approaches and willingness to change major. Chem. Educ. Res. Pract. 14(4), 496-506. http://dx.doi.org/10. 1039/C3RP00045A

Lent, R. W., Brown, S. D., \& Hackett, G. (2002). Social cognitive career theory. Career Choice and Development, 4, 255-311.

Lotriet, H., Matthee, M., \& Alexander, P. (2011). Internet access as a structural factor in career choice: A comparison between computing and non-computing major students. African Journal of Research in Mathematics, Science and Technology Education, 15(2), 138-153.

Lotriet, H., Matthee, M., \& Alexander, P. M. (2010). Challenges in ascertaining ICT skills requirements in South Africa. South African Computer Journal, 46, 38-48. http://dx.doi.org/10.1039/ C3RP00045A

Mao, S. (2013). Students' choice of a business major and career: A qualitative case study of motivation to study finance and banking (Doctoral dissertation, Victoria University of Wellington). Retrieved from http://researcharchive.vuw.ac.nz/handle/10063/3030

Mikva, K. (2015, June). Best-paying jobs in South Africa. AFK Insider. Last accessed 29 Jun 2016. Retrieved from http://afkinsider.com/59779/best-paying-jobs-south-africa/

Mishra, S., Draus, P., Caputo, D., Leone, G., Kohun, F., \& Repack, D. (2013). Gender rationales in selecting a major in information technology at the undergraduate level of a university program: A focus group approach. In Proceedings of the information systems educators conference (Vol. 2167, p. 1435). Citeseer. Retrieved from http://citeseerx.ist.psu.edu/viewdoc/ download?doi=10.1.1.401.4\&rep=rep $1 \&$ type $=$ pdf

Moyo, A. (2015, June). ICT skills outsourcing hurts SA economy. Last accessed 29 Jun 2016. Retrieved from http://www.itweb.co.za/index.php?option=com_content\&view=article\&id=143798: ICT-skills-outsourcing-hurts-SA-economy\&catid=86

Mui, G., Tee, Y., \& Sien, V. (2013). Perceptions of Information Communications Technology education: A supply-side case of Malaysian private education. In PACIS 2013 proceedings. Retrieved from http://aisel.aisnet.org/pacis2013/208/

Myers, M. D. \& Newman, M. (2007, January). The qualitative interview in IS research: Examining the craft. Information and Organization, 17(1), 2-26. http://dx.doi.org/10.1016/j.infoandorg. 2006.11.001

National Association of Colleges and Employers. (2014a, May). Class of 2014: Top-paid business majors. Last accessed 29 Jun 2016. Retrieved from https://www.naceweb.org/s05282014/ top-paid-business-majors.aspx

National Association of Colleges and Employers. (2014b, April). Salary survey: Top-paid majors for the class of 2014. Last accessed 29 Jun 2016. Retrieved from https://www.naceweb.org/ s04162014/top-paid-majors-class-of-2014.aspx

Noble, K. D. \& Childers, S. (2008). A passion for learning: The theory and practice of optima match at the University of Washington. Journal of Advanced Academics. http://dx.doi.org/10.4219/jaa2008-774 
Reck, S. J., Stratman, E. J., Vogel, C., \& Mukesh, B. N. (2006). Assessment of residents' loss of interest in academic careers and identification of correctable factors. Archives of Dermatology, 142 (7), 855-858. http://dx.doi.org/10.1001/archderm.142.7.855

Riesen, A. M. (2011). The choice: Art of science (Cand. thesis, Oregon State University). Retrieved from http://ir.library.oregonstate.edu/xmlui/handle/1957/20852

Roach, D. W., McGaughey, R. E., \& Downey, J. P. (2011). Selecting a business major within the college of business. Administrative Issues Journal, 2(1).

Sanders, I. D. \& Alexander, P. M. (2015, December). A study of computing doctorates in South Africa from 1978 to 2014. South African Computer Journal, (57). http://dx.doi.org/10.18489/sacj. v0i57.294

Schofield, A. (2014). 2014 Joburg Centre for Software Engineering ICT Skills Survey Report. Last accessed 29 Jun 2016. Retrieved from http://www.jcse.org.za/sites/default/files / \%5Bfilename\%5D\%5F2.pdf

Scott, I., Yeld, N., \& Hendry, J. (2007). Higher education monitor: A case for improving teaching and learning in South African higher education. Council on Higher Education Pretoria.

Seymour, L., Hart, M., Haralambous, P., Natha, T., \& Weng, C.-W. (2005, December). Inclination of scholars to major in information systems or computer science. South African Computer Journal, 35, 97-106.

Shackelford, R., Lunt, B., McGettrick, A., Sloan, R., Topi, H., Davies, G., ... LeBlanc, R. (2006). Computing curricula 2005: The overview report. In Proceedings of the 37th SIGCSE technical symposium on computer science education - SIGCSE '06. Association for Computing Machinery (ACM). http://dx.doi.org/10.1145/1121341.1121482

Sife, A., Lwoga, E., Sanga, C., et al. (2007). New technologies for teaching and learning: Challenges for higher learning institutions in developing countries. International Journal of Education and Development using ICT, 3(2).

Smit, R. (2012). Towards a clearer understanding of student disadvantage in higher education: Problematising deficit thinking. Higher Education Research \& Development, 31 (3), 369-380. http://dx.doi.org/10.1080/07294360.2011.634383

Tanner, M. \& Seymour, L. (2014). The range and level of software development skills needed in the Western Cape, South Africa. In Proceedings of the e-skills for knowledge production and innovation conference 2014, cape town, south africa (pp. 487-505). Retrieved from http://proceedings.eskillsconference.org/2014/e-skills487-505Tanner814.pdf

Topi, H., Valacich, J. S., Wright, R. T., Kaiser, K., Nunamaker, J. F., Jr., Sipior, J. C., \& de Vreede, G. J. (2010). IS 2010: Curriculum guidelines for undergraduate degree programs in Information Systems. Communications of the Association for Information Systems, 26(18). Retrieved from http://aisel.aisnet.org/cais/vol26/iss1/18

University of Cape Town. (2015). INF1002F Information Systems 1. Online. Last accessed 29 Jun 2016. Retrieved from http://www.commerce.uct.ac.za/InformationSystems/CourseInfo/ INF1002F

US Department of Labor. (2010). Bureau of Labor Statistics Occupational Outlook Handbook. Last accessed 29 Jun 2016. Retrieved from http://www.bls.gov/ooh/ 
Volman, M. \& van Eck, E. (2001). Gender equity and information technology in education: The second decade. Review of Educational Research, 71(4), 613-634. http://dx.doi.org/10.3102/ 00346543071004613

Whelan, E. \& Firth, D. (2012). Changing the introductory IS course to improve future enrollments: An Irish perspective. Journal of Information Systems Education, 23(4), 395.

Zachariadis, M., Scott, S., \& Barrett, M. (2013). Methodological implications of critical realism for mixed-method research. MIS Quarterly, 37(3), 855-879. Retrieved from http://misq.org/ methodological-implications-of-critical-realism-for-mixed-methods-research.html

Zafar, B. (2013). College major choice and the gender gap. Journal of Human Resources, 48(3), 545-595. http://dx.doi.org/10.3368/jhr.48.3.545 